\title{
The Influence Of Interpersonal Communication Towards Motivation To Increase Income Survey On Samosir Regency And Simalungun Regency
}

\author{
H. D. Melva Sitanggang \\ University Of Prima Indonesia \\ melvaunj@gmail.com-R14093
}

\begin{abstract}
The purpose of this research done is to find out how big the influence of interpersonal communication towards motivation to increase income of community who is located around the Lake Toba.

This research was carried out by using method survey by taking as many as 80 people respodens who live around Lake Toba in Simalungun Regency Regency and Samosir Regency, North Sumatra Province.

The results of this research are expected to give implications of community's participation in improving the hight determination of interpersonal communication and the motivation in raising revenue.
\end{abstract}

Key Words: Interpersonal Communication, motivation in increasing income. Simalungun Regency and Samosir Regency, North Sumatera Province.

\section{Introduction}

Tourism has been showing his role with real life contributes to the economic, social and cultural nation. Job opportunities for skilled people in this field grew in number, State revenue from taxes and foreign exchange sectors grew, the social circumstances of communities involved in this sector more and more good, more and more people acquire cultural appreciation.

In Indonesia, there are a lot of the areas of tourism that can increase the Country's Foreign Exchange but the most popular is currently just the Island of Bali. Regional tourists in Sumatra are also not less beautiful if we compare to Bali. It may be caused by the lack of available improvements to tourist attraction offers that made by the Local Government. Related to tourism promotion conditions between one area where the area is strongly supported by community properties that relate directly to the tourists who visit to a tourist area.

Samosir Regency's vision for tourism in 2010 will not be fulfilled if there is no co-ordination of the parties related to the development of tourism, especially from the role of the community which is directly related to the local and overseas tourists. Samosir Regency and Simalungun Regency Government that relate directly to the Lake Toba tourism are very seriously in an increasing number of tourists who will come to the Lake Toba.

An increase in tourist arrivals to Lake Toba will contribute towards regional development regencies and communities that exist in the area of Lake Toba.

Based on observation done that the arrival of foreign tourists come to Lake Toba almost entirely have received information from various source of information.

In raising visits foreign tourists, the regencies government should be on both the regency who have to involve public in increasing arrival foreign and domestic tourists.

Beside introducing the beauty of Lake Toba, they also must introduce the culture of existing in Samosir Regency and Simalungun Simalungun.

The tourism sector, while it is noted seriously then it will contribute to the Country's Foreign Exchange Income with an increase in tourists visit foreign countries to come on one particular tourism objects.

We must evaluate totally all sectors related to tourism, including tourism institutions, including tourism educational institutions. It was supposed to Tourism Vocational High School in Samosir took part in the development of tourism by working together with Higher Education Institutions as well as other tourism joined The Association Of Higher Education Institutions Of Tourism (AHI). The Graduate School of Tourism should give a chance as the planners and implementers. Indeed it concerns, while it still lacks the power of tourism graduates who are given the opportunity to actualize the results as long as he gets the education school in Tourism Vocational High Scool. There are benefits to open Tourism Vocational High School. Now it is time for the graduates Vocational High Schooll already can directly participate to the develop of tourism in Samosir. In a less successful development of tourism in an area then we have to find what the root of the problems that exist in the area. 
Tourism must be able to become one of strength because of tourism was the link to the development of other sectors in income enhancement of a region. Tourism as an industry that is spatially the labor-intensive and also serves as catalyst in the development and accelerate the process of fair income distribution of society. The arrival of foreign tourists unambiguously will improve foreign exchange revenue of the country. In the period of 1996 to 2002, in fact that it turns out that the tourism sector is ranked second after petroleum and natural gas in order to improve foreign exchange of the country. The purpose of the development of tourism, it is not only to raise Foreign Exchange Revenue State, of course, but also expected to be as catalyst of development (agent of development). Therefore, it is expected that the community can give a good image for tourists who come to the tourist areas because Indonesia has a specific characteristic and a distinct identity with other countries. Nation of Indonesia should be able to put the nation's arts and culture as a wealth (assets) that can serve as tourist attractions that needs to be kept its existence.

In the economy of a country where tourism is developed in a planned and integrated, so the tourism sector will be able to exceed the sector of petroleum and natural gas. Therefore, the development of tourism can be a double multiplier effect, which is in addition to an increase in foreign countries can also improve the economy of communities surrounding the area of tourism.

One of the keys to success in developing the tourism sector in Indonesia is the existence of synergies from the various parties concerned are carried out professionally. When the paradigm can be developed appropriately and correctly, then the tourism sector will be able to bring a more comprehensive benefits on society, both in terms of economic and other benefits related to the interests of society and the State. Therefore needed a policy to maximize the positive effects and minimize the potential negative impacts of tourism itself.

Development of tourism sector very closely related to natural and human resources available. These two factors are strength in global competition in low competition of people against tourist destinations in order to prepare and manage tourism object compared to other regions. Human resources was very influential against tourist attraction in terms of both ways, their ways of knowledge, local community in serving and communication data tourists visit. Therefore, then one factor that need immediate improvement is been the motivation public education and in the efforts to build tourist destinations.

Up to now the Lake toba, located on Samosir Regency and Simalungun Regency has become tourist destination so that the planning of tourism is already a must yangmenjadi it is important to maintain the sustainability of tourism in both districts.

Good planning will result in an increase in the competitiveness of the product strategy and the benefit that will provide benefits to the communities and regions.

The base of sustainable development is the preservation of natural resources and culture where resources was everybody needs time now to live a life and prosperous, but must be kept and preserved in order to be used in the future would go so that the sustainability of human life will be guaranteed to preserve the existing natural.

\section{Formulation Of The Problem}

Based on basic problems that have been described, problems in the background our problems in research is formulated as follows:

"Is there the influence of interpersonal communication to people's motivation against the community in tourism environmental conservation?"

\section{The Benefits Of Research}

\section{Theoritical Benefits.}

For the researchers, this research result will be expected that it may have benefits as reading materials and basic further research agencies, especially against the new variables that can impact on public participation in the environment tourism.

\section{Applicative of Benefits.}

The results of this research are expected to give an explanation of the things that can determine the formation of community participation in environmental conservation tourism.

For policy makers, the results of this research are expected to be input and consideration in drawing up the strategic plan and provide knowledge about the environment in shaping society's motivation for participating in environmental conservation tourism

\section{The Level of Interpersonal Communication (X).}

Etymologically, the word communication comes from the Latin, namely: communicatio and derived from the word communis which means the same or similar meaning. Thus, if two or more persons are engaged in communication then communication will occur or lasted as long as there are similarities about what the 
meaning of that discussion in that conversation, not necessarily gives rise meaning. Thus, it is said to be communicative when both are in addition to understand the language used also about the meaning of the discussion material. (Larry, 2003).

In communication of course there ' s personal and there is that an organization because it has been represented a group of people.

Wiryanto, 2010 says that organizational communication is the sending and receiving of various organizational messages in formal or informal groups of an organization.

According to Joseph A. Devito (2001:4) in his book The Interpersonal Communication Book, says that interpersonalcommunication is the Process of sending and receiving messages between two respons, or among a small group of person with some effect and some immediate feedback. Communication as a transaction, in the context of this communication is a process of personal meaning or understanding as acquired essentially private. Excess of conceptualization of communication as is the communication transaction is not limited on a deliberate communication or response that can be observed. This means that the communication happens whether the perpetrators intentionally or not, and even generate a response that cannot be observed.

Denis Mc. Quail (2001) says that the best way in describing communication is by answeringthe questions Who says, What, which Channel to Whom sith, What effect?

Onong Uchana Effendi (2006) says that communication consists of personal communication, group communication, mass communication, and medio communication. The interpersonal communication itself consists of intrapersonal communication and interpersonal communication. Intrapersonal communication is also often mentioned as interpersonal communication or communication between two persons. Interpersonal communication happens betwee two persons (communicator and communicant), its nature and takes place in dialogis reciprocity (two waytraffic communication) which reserve the current (its feedback) soonly happens that the communicators directly can obtain the communicant's reaction at the same time.

According to Deddy Mulyana (2007), that interpersonal communication is communication between people faceto-face, allowing each person captures the reactions of others directly either in verbal or non-verbal.

Dean C. Barnlund (2001), says that interpersonal communication is interpersonal communication which is always connected with the meeting between the two, three or maybe four people happened spontaneously and is not structured.

While Everett M. Rogers (2004 defines that Interpersonal communication is communication by word of mouth occurring in face-to-face interaction between some personal.

Alexis Tan (2002) expresses that communication between personal face-to-face communication is between two or more people.

According to Jalaluddin Rakhmat (2004), that interpersonal communication has 3 (three) features a very prominent communicators namely credibility, attractiveness and power.

In the framework of environmental conservation tour of interpersonal communication that is done should be directed at efforts to: 1. manifest, cultivate, develop and raise awareness of the rights and responsibilities of the community in the management and preservation of the environment tours; 2. realize, develop, grow and increase the motivation of the community in the management and preservation of the environment of tourism; 3. manifest, cultivate, develop and enhance active participation (participation) of the community in environmental conservation efforts and tourism; 4. explain the program and the wisdom of the Government's response to the environmental conservation efforts of tourism; 5. explain about efforts that are proactive and prefentif should be done by the Government and the community in prevention efforts decline in environmental quality tourism; 6 . explain the benefits and technological development familiar with tourism environment; 7. provides information about the environment and environmental tourism and disseminate to the public.

Based on the above description can be composed in a nutshell about interpersonal communication to then synthesized.

\section{People's Motivation (Y).}

The motivation comes from the Latin word "movere", from which means encouragement or move. Along with the development of management science and understanding the motivation has many changes.

According to Cherrington, motivation is a condition that moves mankind toward a particular goal.

According to Fisher et. al, that motivation is the result of a process that is internal or external to the individual, leading to the onset of the attitude of enthusiasm and persistence in carrying out certain activities.

Willian G. Scott (1990), defines that motivation means a process of stimulating people to action to accomplish desired goals.

Dessler (1994) also defines that motivation as a contributing condition raises, directs and maintains the behavior that relate to the environment in where one lives. He said that the attitude of motivation of an 
employee in the face of situations. Motivation is a condition that drives the employees guided to achieve the objectives of the organization.

Togu Harlen Lbn. Raja (2010) says that motivation is the process of uplifting work that pushed in carrying out its work in order to achieve the goal.

Stephen P. Robbins (2000) expresses that individuals will be motivated doing activities when the individual concerned to see that the activities meet the needs at the time.

Maslow expresses that this theory was developed based on three dimensions, namely: a. man is "wanting beings" who are motivated by a desire to gratify their various needs. Need for it is not going to move comportment, is sated but needs which is sated not act as motivator; B. the needs of someone are arranged in a hierarchical the level of the most basic until the highest level; C. the needs of someone moving from the rate of the lowest to the next level.

According to Victor H. Vroom, that someone has a tendency to act in a certain way depends on the strength of a hope that it will be followed by a specific output and on the attractiveness of the output for the individual. In more practical terms, an individual is motivated to exercise a high level of effort when he believes the effort will send to a good performance appraisal; a good judgment will encourage the rewards-rewards such as bonuses, a raise, or a promotion, and rewards that will satisfy individual's personal goals.

The theory of expectation from Victor $\mathrm{H}$. Vroom says that the results of the three kinds of feeling: valence, hopes and was instrumental. Valence of reward is the relative strength of the wants and needs of most needed someone to be the strengths of someone's choice of a particular result. Hope (expetancy) is an individual belief that a particular behaviours (effort) will be followed by specific results (performance). Whereas the instruments which is the belief of the individual that his success (performance) made him receive rewards.

Based on descriptions of the motivation of the society according to the experts of communication that has been described above, the definition of the communication society is a strong impetus for the individual community to do something that the valence or desire from the community in carrying out the activities and any hope of obtaining reward and confidence will receive a reward when activities were carried out properly.

\section{Mind Framework.}

Mind framework of this research refers to the theory of models which built by limiting issues as described above, then composed frame as follows: "Direct influence level of interpersonal communication to motivation against people's income in the preservation of the environment."

Interpersonal communication is communication that take place face-to-face between two or more persons in the delivery of a message from the Communicator to communicant so that it can provide a feedback effect. In conveying information to the public to be able to hold the prevention of damage to the environment and protection of natural resources. This is done by the relevant agencies and it takes credibility of communicators.

So the importance of government organizations in motivating the community, then its existence should make a positive role for carrying people. With the presence of leaders of government organizations in communicating and delivering motivational encouragement to the community about environmental preservation so that society will be more motivated, more vigorous and more productive spirit in carrying out environmental preservation.

This condition seems to be experienced by the existing community in the region of Lake Toba. In many places it still encountered a number of people who don't care about the environment and are likely to do something to suit his interests without regard for the environment so that the contamination occurred, changes in lifestyle and motivation for preserving the environment is less prominent, and activities that do not reflect positive behaviors on the environment .

In this context, the communication of government as one of efforts to foster a productive working attitudes and behavior of the community in preserving the environment becomes very relevant to tourism we examine further. Communication of government is becoming more important because however so work plan that has been created by the government in the optimally preserve the environment tours, but if it is not communicated to the community then the work plan there will be no meaning at all. Therefore, the process of delivering the message of the government's people to the community must be done well.

In this framework, it is essential that the title became the power should not be forgotten. Through the credibility and appeal of the apparatus that is, the public will be effectively terpersuasi than second without it.

It is expressed by Alexis Tan (2001:106), that credibility of communicators is the impression of communicant which is related to depend on the skill, trust, personality and dynamic communicator. While the impression of communicator is also as the communicant's impression about communicator himself which can be seen by the similarity, familiarity, close, physical impression and his ability. 
Communicator's credibility is the communicant's impression that concerns about the skills, confidence, charisma and dynamism of communicators. Whereas communicators attraction is communicant's impression about communicator is seen in terms of similarities, familiritas, proximity, physical attractiveness and abilities.

\section{Hypothesis Of Research.}

Based on the theoritical framework and mind framework which is expressed above, so the hypothesis of this research can be formulated as follows:

"It can be found the direct positive influence between the level of personal communication (X) towards people's motivation $(\mathrm{Y}) . "$

$\mathrm{H}_{\mathrm{o}}: \mathrm{P}_{21}=0$

$\mathrm{H}_{1}: \mathrm{P}_{21}>0$

\section{Methodology Of Research.}

This research was carried out with the purpose to express whethere there is the direct influence of interpersonal communication between levels of motivation increasing people's income, environmental conservation or not, in Simalungun Regency's and Samosir Regency's tourism in North Sumatra Province.

The methodoligy of this research is by using survey method with causal approach. Causal approach which is used in data analysis techniques is by using path analysis where this analysis is used to test direct or indirect influences between variables.

\section{Location of Research.}

Location of this research is done in the area of Lake Toba which is located in Simalungun Regency and Samosir Regency in North Sumatera Province. Data is was obtained by using research instrument which has been tested its validity and reliability.

\section{Population and Sample.}

The population used is the second community in the county (regency) that has to do with tourism activities and the randomly chosen respondents in the number of 80 people who have anything to do with tourism activities.

As respondents taken is people who live in nearby the area of Lake Toba namely the society of Simalungun Regency and Samosir Regency in North Sumatera Province.

The target sample of respondents is allowed as a community that exists around the Lake Toba tourism area of Simalungun Regency and Samosir Regency in North Sumatra Province.

\section{Technique of Collecting Data.}

The technique of collecting data should be conducted by way of begging and collect respondents elected from both district in village and henceforward be interviewed and given the opportunity to fill a questionnaire where a questionnaire used to obtain data judgment about the whole variable.

Data used in this research are:

1. Endogenous variables measuring instruments communities where motivation is designed by presenting questions to be delivered to the respondents and any instruments used in the form of a questionnaire with the five ranges of answers and each question comes with five choices of measurements and a choice answers as follows: score of (5) to the answer is very encouraging; score of (4) to the answers often push; score of (3) to the answer of sometimes push; score of (2) to the answer almost never pushes; and the score of (1) had not been encouraging.

2. Exogenous variables are the level of interpersonal communication and research instrument which was designed by presenting questions to be delivered to the respondents where every instrument used in the form of questionare with the five ranges of answer and each question comes with five choice of measurements and a choice answers as follows: score of (5) always; score of (4) often; score of (3) sometimes; score of (2) almost never and score of (1) never at all.

The procedure of the implementation of the trial an instrument is:

1. Determine respondents trial;

2. The test;

3. Analysis of instruments.

Preparation of the questionnaire itself is done through planning with the following steps:

1. To identify the purpose of the measurements of the variables that will be measured;;

2. To see the contents gauge is in accordance with that will be measured;;

3. To see and to identify the items in accordance with the theoritical concept. 
According to Uma Sakaran (2000) that test samples should be outside research but the condition is more or less the same with the amount of research with a sample of 30 to 50 respondents and conducted the final stage of analysis instrument to see the extent to which the instruments that can measure what it wants to measure the views of validity and reliability.

Furthermore Kerlinger (1993) says that there are three kinds of the way in measuring validity of instruments, namely:

1. The validity construction.

2. The validity over.

3. The validity of its contents.

In research is using validity construction it means drafting instrument based on theoretical study by which an instrument that both in conceptual done having validity construction good when performed analysis grains with means correcting score any grains about the score by difference.

In this study the technique of correlation used are product moment correlation technique (person) that is using the coefficient of correlation between techniques scoring points with the total score ( $\mathrm{r}$ count).

Criteria testing by way of comparing prices between t-count t-table Alpa $5 \%$.

In the meantime to test reliability analysis used Sparmen Brown with a "Split Half" methods (test side two) where this way selected in accordance with the instruments to dig and assessment experience. This analysis procedure at once gives an overview about the consistency of its homogeneity based on grains as well as having relevance to the instrument validitasdankonstruk instruments.

In collecting data by using the research instrument that was based by definition of conceptual and operational definitions and Itsindicators.

Furthermore, the grating research is composed as follows:

Grating Instrument Of Interpersonal Communication

\begin{tabular}{llll} 
ASPECTS & \multicolumn{2}{l}{ INDICATORS } \\
(1) & (2) & \\
1. & Communicator's credibility & 1. & Communicator's physical appearance. \\
& 2. & Communicator's propinquity/familiarity. \\
& 3. & Communicator's similarity. \\
4. & Communicator's attractiveness & 1. & Communicator's expertise. \\
& 2. & Communicator's dinamism. \\
& 3. & Communicator's sharismatic.
\end{tabular}

\section{A Grating Research Instruments Motivation Increase Income}

\begin{tabular}{|c|c|c|c|}
\hline $\mathbf{A S}$ & & IN & ORS \\
\hline (1) & & (2) & \\
\hline 1. & Valence & 1. & Desire of obtaining income \\
\hline & & 2. & Desire of getting decent job \\
\hline & & 3. & Desire of a decent livelihood. \\
\hline 4. & Expectation & 1. & Chances of obtaining income \\
\hline & & 2. & Chances of getting a decent job \\
\hline & & 3. & Chances of a decent livelihood. \\
\hline 4. & Instrumentation & 1. & Belief of making money \\
\hline & & 2. & Belief of getting decent jobs \\
\hline & & 3. & Belief of a decent livelihood.. \\
\hline
\end{tabular}

\section{Result Of Research.}

Based on data given through search to the court and performed validation and reliability and hence obtain data that can really answer the problems.

The Data is analyzed and processed by using analytical tools to address existing problems and the data cannot be manipulated to deliver results in accordance with the wishes of the researcher.

Causal relationships between interpersonal communication and motivation variables of income can be seen in the following table:

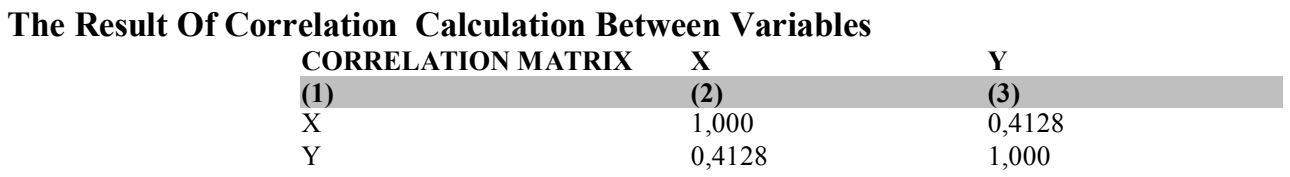

Based on Matrix Correlation between variables, to the next to count Inversion Correlation and can be seen on the table below. 


\section{The Result Of Calculation Of Inversion Matrix}

$\begin{array}{lll}\text { MATRIKS INVERS } & \mathbf{X} & \mathbf{Y} \\ \mathbf{( 1 )} & \mathbf{( 2 )} & \mathbf{( 3 )} \\ \mathrm{X} & 1,205 & 0,498 \\ \mathrm{Y} & 0,498 & 1,205\end{array}$

After having obtained the correlation matrix and matrix Inverses, then the next variable is done between each coefficient calculation lines and can be assessed on the following table:

\section{The Result Of Reckoning The Coefficients}

$\begin{array}{ll}\text { RECKONING COEFFICIENTS } & \text { RECKONING COEFFICIENTS } \\ \text { (1) } & \text { (2) } \\ \text { YX } & \text { P2 }: 0,2959 \\ \text { YX } & \text { P22:0,6514 }\end{array}$

\section{Source: Data Analysis.}

Based on the diagram of reckoning, acquired two pieces of line coefficients, namely: $\mathrm{P}_{21}$ and $\mathrm{P}_{22}$ and the coefficient of correlation of $r_{11}$ and further from the results of calculation of coefficient multiplication using matriksesuai with the workflow path analysis, the value of the coefficient of each path is calculated and tested some importance.

To test which use the overall $\mathrm{F}$ test and use of individuals using the test $\mathrm{t}$. The calculation result overall test $F$ was 11,723 and $F_{\text {table }} 0,05=2,645$. While the results of the calculation with the t-test is $P_{21}=2,946, P_{22}=$ 9,08 . Now $t_{\text {table } 0,05}, 78=1,6888$ and $t_{\text {table } 0,01},=1,6888$ so the decision is that $H_{0}$ is refused if $T_{\text {count }}>t_{\text {table. The }}$ result of calculation of $F_{\text {count }}=177,77$ while $F_{\text {table }}=2,544$, so $F_{\text {count }}>F_{\text {table }}$.

\section{Result Of Hypothesis.}

The withdrawal of conclusion hypothesis was conducted through a calculation of the value of the coefficients jalurdan significance to any path subjects. The results of a decision against a whole hypothesis advanced by described as follows: that interpersonal communication directly influence against motivation society.

The tested hypothesis is:

$\mathrm{H}_{\mathrm{o}}: \mathrm{P}_{21}=0$

$\mathrm{H}_{1}: \mathrm{P}_{22}=0$

Based on calculations about the influence line of analsis communication interpersonal retrieved direct path coefficient of $\left(\mathrm{P}_{21}\right)=0,2959$ with $\mathrm{t}_{\text {count }}=3,9449$; while $\mathrm{t}_{\text {table }(0,05)}$ so that the coefficient significant lines. Therefore, the hypothesis that says that there is a direct influence of interpersonal communication community motivation may be accepted. Terms of this can be indicated that interpersonal communication is a direct effect on the motivation of the people.

\section{Conclusion.}

Based on the analysis and discussion of the themes of this research, the following conclusions can be taken, that the level of Communications Personnel (X), the direct effect of community motivations (Y) in a positive and significant at the $\alpha=5 \%$ with a value line of 0,2959 .

\section{Suggestions.}

Advice would give a response to the conclusions that have been described for obtaining lebihbaik results in the foreseeable future.

Based on the conclusion that has been put forward so it can be given suggestions as follows:

1. It is needed to attempt to keep doing personal communication to the community. The results of this research proves that the communication made by the Government apparatus in the field environment has proven to be able to increase the motivation of people to participate in conserving the environment of tourism in the Lake Toba region.

2. At the time of performing personnel communication, that must be considered is associated with attractiveness and credibility of a communicator (government officials), so it should be local authorities have to choose people actually have attractiveness and credibility in the eyes of the public, communicators so what is delivered in the form of a message to participate in carrying out the environmental conservation tourism acceptably well by comunicant (society).

3. The motivation of community can be ditinkatkan by means of: a. The Government official regularly (periodic) should continue to provide the message contains encouragement to continue to participate in conserving the environment of tourism; b. Improve education and public awareness of the importance of community participation in tourism so as to preserve the environmental sustainability of tourism that can be maintained. 


\section{Bibliography}

[1]. Anwar, Arifin, 2006, Ilmu Komunikasi, PT. Raja Grafindo Persada, Jakarta

[2]. Cerrington, David J. 1995, The Management of Human Resources, 4 edition, Prentice Hall International.

[3]. Deddy, Mulyana, 2007, Ilmu Komunikasi Suatu Pengantar, Remaja Rosdakarya, Bandung.

[4]. Dessler, Gary, 2000, Organizational Theory, California, Seventh Edition, Prentice Hall International, Inc.

[5]. Prijono, Tjiptoherijanto,2005, Mikul Dhuwur Mendham Jero, (Pemikiran Politik dan Reformasi Kependudukan), Fakultas Ekonomi, UI, Jakarta.

[6]. Kerlinger, F.N. 1993, Azas-azas Penelitian Behavioral, Terjemahan, Magdalena, Erlangga, Jakarta.

[7]. Robbins, Stephen P. 2001, Orgaization Behavioral, Fifth edition, Prentice Hall International, Inc New Jerzey.

[8]. Sekaran, Uma, 2000, Research Methods for Business, $3^{\text {th }}$ edition. John Willey and Sons, Inc. New York.

[9]. Scot, K. D., and E. L. McClellan, 1990, Gender Differences in Absenteeism, Public Personnel Management, McGraw Hill, Inc. New York.

[10]. Togu Harlen Lbn. Raja, 2010., Manajemen Personalia, Professional Press, Medan.

[11]. Wiryanto,2004, Pengantar Ilmu Komunikasi, PT. Gramedia Widiasarana Indonesia, Jakarta.

[12]. Wright Glerhart, 2008, Human Resources Management, $4^{\text {th }}$ Edition, Prince McGraw Hill International. 